\title{
GROUND TRANSPORTATION AND NEW INTERCONNECTIONS BETWEEN AYMARA SOCIETY AND THE ECONOMY
}

\author{
TRANSPORTE TERRESTRE Y NUEVAS INTERCONEXIONES \\ ENTRE SOCIEDAD Y ECONOMÍA AYMARA
}

\author{
Alejandro Garcés H. ${ }^{1 *}$ y Jorge Moraga R. ${ }^{2}$
}

\begin{abstract}
This article explores the development of a transport market which moves passengers and goods over the road system currently connecting Bolivia and Chile. An elite of aymara transport entrepreneurs has emerged in both Colchane and Pisiga to provide these services. This elite has currently been put under pressure by the appearance of new national and international actors. In a context of rural depopulation, migration between cities in both Chile and Bolivia and deterioration of the farming economy, we will see how participation in this transportation market has implied an important source of economic accrual in which indigenous actors have found a place. This process has reconfigured pre-existing political structures and generated new forms of social mobility and economic and political leadership.
\end{abstract}

Key words: Colchane, Pisiga, aymara, transportation, economy.

Este artículo se propone caracterizar algunas de las transformaciones sociales, políticas y económicas al interior del mundo aymara -en tanto grupo étnico predominante en la zona-de las localidades colindantes a la frontera nacional en torno al complejo fronterizo en Colchane-Pisiga, que conecta los territorios de la región de Tarapacá en el norte chileno y el departamento de Oruro en el occidente boliviano, las cuales han sido dinamizadas por el importante auge y desarrollo de la economía del transporte de mercancías y personas en las últimas décadas. Este proceso reconfigura las estructuras políticas preexistentes y genera nuevas formas de movilidad social-económica y liderazgo político.

Palabras claves: Colchane, Pisiga, aymara, transportes, economía.

The object of this article is to characterize some of the social, political and economic transformations within the world of the aymara -as a dominant ethnic group in the region-in localities close to national frontiers. The area studied was that dependent on the Colchane-Pisiga border complex, which connects the Tarapacá Region in northern Chile with Oruro Department in western Bolivia. The economies of these areas have become more dynamic due to the development and growth of goods and passenger transport in recent decades (Figure 1). The work is based on two periods of ethnographic work in the towns of Colchane, Pisiga, Bolívar, Cariquima, Enquelga, Chijo, Pozo Almonte and Alto Hospicio (Iquique), between January and March 2013.

During the 1980s, International Route 15-CH (formerly A55), linking the Chilean town of Huara with the Colchane-Pisiga border crossing, was paved and generally improved. Since then, passenger and goods traffic has increased greatly. According to Chilean Customs statistics (Aduanas 2012), passenger traffic between 1997 and 2004 barely reached 85,000 per year, but numbers have increased strongly since 2005 reaching 400,000 in 2012. In terms of goods, measured in tons, there is also a significant increase to 317,330 tons in 2012, according to the same source. Although these numbers are still well below those of the Chungara Pass, which captures traffic between $\mathrm{La}$ $\mathrm{Paz}$ and the port of Arica, they nevertheless reflect strong growth in flows across that part of the border (Tables 1 and 2).

Based on ethnographic observation, we attempt to show some aymara practices which have sometimes been presented as pure economic

\footnotetext{
1 Universidad Católica del Norte, Instituto de Investigaciones Arqueológicas y Museo Gustavo Le Paige. Calle Gustavo Le Paige 380, San Pedro de Atacama, CP: 1410000, Chile. ajgarces@gmail.com, agarces@ucn.cl.*Autor correspondiente.

2 Universidad Central de Chile, Facultad de Ciencias Sociales. Calle Lord Cochrane 417, Santiago, CP 8330507, Chile. simpulum@yahoo.com
} 


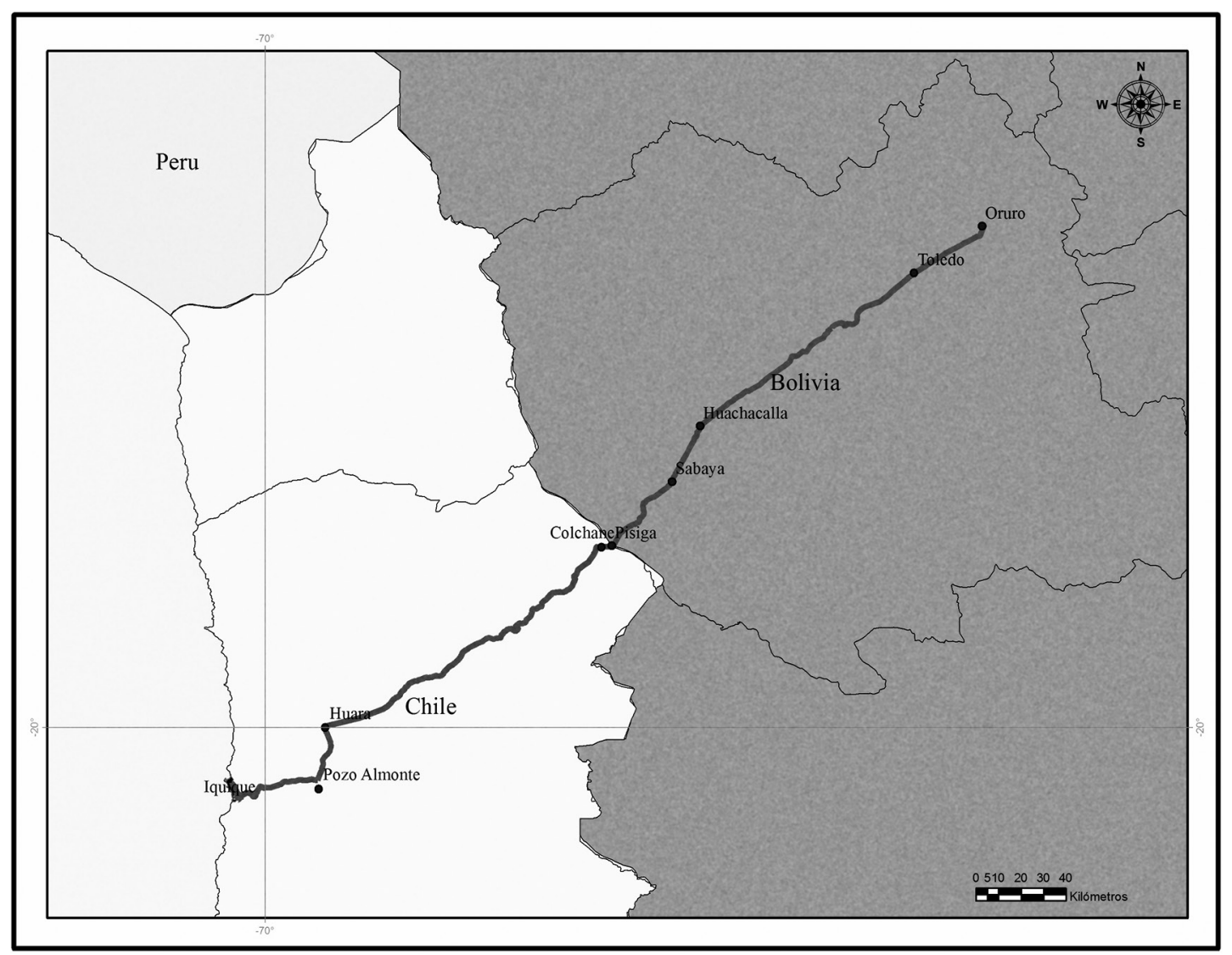

Figure 1. Map of the Iquique-Oruro corridor (making: Ignacio Manríquez).

Mapa corredor Iquique-Oruro (elaboración: Ignacio Manríquez).

Table 1. Border ground passenger traffic (number of passengers).

Tráfico fronterizo (número de pasajeros).

\begin{tabular}{|c|c|c|c|c|c|c|c|c|}
\hline Customs & 2005 & 2006 & 2007 & 2008 & 2009 & 2010 & 2011 & 2012 \\
\hline Visviri & 10,575 & 11,372 & 9,409 & 8,134 & 7,033 & 4,115 & 2,942 & 3,473 \\
\hline Chacalluta & $3,733,427$ & $4,135,374$ & $4,315,140$ & $4,003,856$ & $4,110,642$ & $4,508,000$ & $5,009,029$ & $5,150,971$ \\
\hline Chungara & 275,515 & 338,184 & 409,925 & 442,906 & 470,471 & 480,266 & 550,015 & 566,945 \\
\hline Colchane & 151,786 & 214,374 & 248,189 & 303,849 & 295,354 & 282,726 & 314,202 & 432,598 \\
\hline Ollague & 7,252 & 13,605 & 14,686 & 19,917 & 16,990 & 18,154 & 20,747 & 25,288 \\
\hline
\end{tabular}

Source: monthly averages of Customs border crossings.

Table 2. Border ground goods traffic (tons).

Tráfico fronterizo de mercancías (toneladas).

\begin{tabular}{lrrrrrrrr}
\hline \multicolumn{1}{c}{ Customs } & \multicolumn{1}{c}{2005} & \multicolumn{1}{c}{2006} & \multicolumn{1}{c}{2007} & \multicolumn{1}{c}{2008} & \multicolumn{1}{c}{2009} & \multicolumn{1}{c}{2010} & \multicolumn{1}{c}{2011} & 2012 \\
\hline Visviri & 36,075 & 42,470 & 62,107 & 49,115 & 32,690 & 18,682 & 5,039 & 5,493 \\
Chacalluta & 316,339 & 301,328 & 286,461 & 319,602 & 294,261 & 375,721 & 370,830 & 385,798 \\
Chungara & 999,390 & $1,022,785$ & $1,253,838$ & $1,763,630$ & $1,661,881$ & $2,003,982$ & $2,508,137$ & $2,773,226$ \\
Colchane & $\mathbf{7 2 , 0 1 1}$ & $\mathbf{1 3 2 , \mathbf { 2 7 4 }}$ & $\mathbf{1 7 8 , 2 6 1}$ & $\mathbf{2 3 4 , \mathbf { 5 8 1 }}$ & $\mathbf{1 9 2 , \mathbf { 5 2 2 }}$ & $\mathbf{1 7 2 , \mathbf { 7 8 4 }}$ & $\mathbf{2 2 0 , \mathbf { 3 2 0 }}$ & $\mathbf{3 1 7 , 3 3 0}$ \\
Ollague & 17,832 & 33,700 & 37,214 & 73,613 & 46,366 & 62,414 & 62,484 & 70,777 \\
\hline
\end{tabular}

Source: monthly averages of Customs border crossings. 
strategy in the framework of a rational-utilitarian logic, but which, in the subjects' practice, are conditioned by other areas of social life that refer us to the legitimacy spaces common to a political, ritual and communitarian order.

The text is composed of two main parts. First, we describe the emergence of a transport industry elite in Colchane and Pisiga, led to a great extent by members of the aymara world - mainly families and individuals who already possessed a certain economic position and symbolic or ritual leadership within the communities. It is of interest to observe the appropriation and juxtaposition of economic, political and symbolic capital in these communities, which fluctuate between the deterioration of aymara identity in some cases to the reinforcement of traditional or historic hierarchies in others. Second, we address the emergence of another transport economy which is on the fringe of the capital accumulation by the elite. In the face of the competition established by the big transport enterprises -aymara, Chilean or foreignsignificant numbers of individuals or groups have become small transport entrepreneurs, an economic activity that they complement with traditional farming and live stock activities and with the differentiated use of spaces, both rural and urban, exploited within the framework of contemporary aymara trans-locality. Here we must note an exception. In expounding the following distinction, our object is not to present these indigenous economies exclusively as traditional or non-capitalist formations, but to illustrate how they coordinate and appropriate the new capitalist, national and technological contexts in which they find themselves. As Tassi and other authors have noted in the case of Bolivia, Aymara economies lead to the formation of new ethnic elites which become integrated with global markets by using local patterns and strategies, both long-established and contemporary. In this way they constitute a critique of the essentialist perspectives which explain these economies by comparison with ancient reciprocity systems and traditional family relations (Tassi 2015; Tassi et al. 2014).

\section{The Development of an Aymara Transport Industry Elite}

This section will attempt to analyze the mechanisms by which a transport industry elite has become consolidated within the so-called second phase of modernization processes taking place over the last forty years in Chile, especially after the application of a neo-liberal model during the Pinochet government. This new phase of capitalist expansion has directed the processes of indigenous integration and differentiation, installing structural barriers that have reconfigured local and kinship processes in aymara communities. These structural barriers have mainly taken the form of a new institutionality that has tended to "municipalize" Andean space in both Chile and Bolivia (Burguete 2011; Gundermann 2003; Orellana 1999); to "privatize and alienate" natural resources, especially water and soil resources (Perreault 2006; Yáñez and Molina 2008); and to encourage the introduction of individuals of these communities into private entrepreneurship policies directed by the needs of commerce and national and transnational capitals ${ }^{1}$. Thus, a profound reorganization of the Andean system has taken place, which cannot be understood either as pure disorganization or as pure continuity or anchorage in tradition, but as following a dynamic of change and re-composition understood as two aspects of a single group of phenomena (Gundermann 2003).

These structural readjustments have resulted in two intertwined phenomena which have reconfigured the indigenous landscape, allowing the consolidation of the transport business: the strong migration of high Andean plateau dwellers to the coastal cities, especially during the 1990s; and the re-integration of local spaces in practices that tended to increase their heterogeneity and social complexity. These phenomena were driven by the growth of commerce around the Iquique Free Trade Zone (Zofri) which, although established in 1975, gained importance after the 1990s due to the flexibilization of entry permits for Bolivian trucks; the creation of the Oruro Free Zone (Zofro) in 1991; and the increased flow of goods that resulted from substantial improvements to Route A-55 (currently 15-CH International) between the town of Huara and the Colchane-Pisiga border crossing, paving of which was completed in the 2000s. The last stretch of road on the Bolivian side was opened by President Evo Morales in 2012.

Noting that aymara communities have not presented themselves as passive actors in these changes, we will investigate the mechanisms by which the current transport business elites were formed in their need to adapt and resignify these structuring frameworks. These elites tend to concentrate -not entirely without conflict- both economic and political local power, besides commanding the processes of 
ethnic and religious reconfiguration in the Colchane commune (administrative district). We will attempt to prove that these elites have been able to maintain and even streng then their hegemony over local power (in Bolivia and Chile) by coordinating, to their advantage, the relationships of "equal" recognition within the framework of symbolic-political national power, as well as the "hierarchical" relationships of subordination and debt that have been established traditionally within their own ethnic communities. The distinction between hierarchical relations and those of equal recognition, here presented between quotation marks, tends to omit the multiplicity of nuances in which the interlocking economic, social and political fields manifest themselves, diluting the hegemonic dichotomy between modernity and tradition.

The courses by which families have formed and accumulated economic capital have allowed us to observe the emergence of these processes. The most significant cases of concentration and control of power in a family are sketched in the careers of the García Mamani and Choque families in Chilean territory and the Colques on Bolivian soil. In all three examples the experience of trans-locality that characterizes the contemporary moment is exposed, manifesting the need to move to other Chilean or Bolivian cities in order to commence the process of obtaining and accumulating symbolic and economic capital (Bordieu 1997), either through study, work contacts or business.

Among the Bolivian aymara, Eddie Colque is the owner of the main transport company in Pisiga-Bolívar (Bolivia) and member of a transport cooperative. He remembers his childhood in which life was shared with Chilean aymaras (now important political and transport business figures, according to him), and he mentions with pride that he is an agronomist and that he started his studies in the Universidad de Tarapacá (Chile):

I have known the mayor [of Colchane], Teófilo [Mamani].... from childhood. He was a haulier. I was an agronomist. I am an agricultural engineer [...]. I know the University of Iquique, because I had to study there... but the costs were a bit... too high, so that I stayed here [studying] in Bolivia.

Colque was mayor of Pisiga-Bolívar between 2009 and 2012. Currently he is recognized as the jilakata $^{2}$ of the town, a traditional aymara authority equivalent to the tribal leaders that the Chilean Aymara area attempting to establish in their sector. On March 2013 he headed the occupation of customs offices in the Colchane-Pisiga border crossing complex, protesting together with a group of hauliers and other traditional authorities (among them his relative Ludger Colque) against the change of Pisiga customs officers, who -they claimed- hindered the introduction of goods from the Zofri.

Among the Chilean aymara, David García Mamani, a member of the family that owns "Transportes García", confirms the necessary stage of accumulation of economic capital in the city. His family managed a chain of butcheries in Alto Hospicio, developing contacts with providers in Osorno, Lo Valledor (Santiago), Paraguay, Argentina and the United States. He worked in the family meat business until 2009, when he decided to gather together part of his wealth and return home to Colchane in the high plateau, where he established a hotel to exploit tourism:

I worked in (...) one of the butcher shops that I owned, I managed the shop and so on; currently my brothers are there working, in other words, the business is more or less established. We have been in the business for about 20 years, so you get a bit saturated too, because you have to be there everyday.

The story of "Transportes García" is typical. In 1994 they began with rural passenger transport between Iquique and Colchane. Towards the end of the decade, taking advantage of Alto Hospicio's explosive population growth, they introduced two small taxi-buses to serveroutes covering the 12 kilometers down a steep cliff that separate the town from the port of Iquique. At that moment they started a trade association "Transatélite A. G." and in 2004, after Alto Hospicio was officially made a commune, they obtained the concession to operate the local transport business. Currently they have a big passenger transport fleet serving the Collahuasi, Gaby, Zaldívar and other mines.

The "Buses Palomo" transport company, which enjoyed its golden age in past decades, is also linked specifically to the Mamani García family. After some years offering a strong alternative for passenger transport between Iquique and Oruro, it is now in evident decline due to the competition of 
national lines, both Bolivian and Chilean. Buses Palomo offers only two buses per day from Iquique, a small share in the daily flow of over twenty buses offered in total by other companies. According to one member of the family: "Currently in the Colchane region there is only one entrepreneur, well actually a micro-business, right? And he... the one with buses [Palomo], is the only one, the only person here in the region...".

Despite its small share in the passenger market, the local transport business has enabled an important accumulation of capital in the region. The Choque family, for example, is also part of this elite that has reinforced its capital by expanding the business, increasing the social differentiation now present in communities of original peoples. In his statement, one aymara small businessman, who currently only operates one truck and offers small cargo services in the city, criticizes the disadvantages faced by small hauliers in competition with the powerful families of Colchane:

the Choque too, they have grown a lot; Gregorio Choque they are called... uuuh!, they are big businessmen now. They grew as a family...of course! (...) That's it, because the rest of us, we are doing so-so, one little truck, two little trucks.

The Choque family has also become famous for establishing associative links that defend the interests of the aymara transport group. According to the same informant:

suddenly they made more associations that have offices now, some associations in the Zofri such as "Transportistas de Autos para Bolivia" (Car transporters to Bolivia). That's where the Choques are also involved, but that is another Choque... but here there is another Choque, Elvis Choque... the Choques are a big family.

The development of these economic capitals has been accompanied by the accumulation of political capital; these families have established themselves as new actors in national political systems. Such is the case of transport entrepreneur Eddie Choque, mentioned above, who was deputy mayor of PisigaBolívar. Later, in 2009-2012, the position was filled by his relative María Colque Caniviri. But he was immediately elected to another important post: "indigenous deputy mayor". In his own words:

Then in 2009 I was deputy mayor, 200910. Last year I was leaving office, on April 28-29. Now, once again, they have chosen me as indigenous deputy mayor, what I will to do is to pay a service to the people, with that I feel whole, I have passed my positions...

The power of the "Colque clan" can be clearly appreciated by looking at the names of the authorities elected last year: councilor, Jorge Colque; municipal deputy mayor, Williams Colque; president, vice president and secretary general of the Pisiga civil society committee, Daniel Colque, Ramiro Moya and Edwin Colque respectively. Secretary of the Safety Committee, Elizabeth Colque.

Among the Chilean aymara, family relationships are also responsible for organizing local political power around traditional lineages, both in national representation and in "indigenous" posts. In 2012, the people of Colchane also saw the office of mayor transferred from Honorio Mamani to Teófilo Mamani, both in the transport business. Despite representing different political views, they both belong to the same family. A similar case is found among council candidates such as Doris Mamani, sister of the current mayor, who accused her relative of blackmail before the Election Qualifying Court (TRICEL).

The current native chief of Isluga is the mayor's father, in a fusion of family interests that summarizes indigenous and national representativeness. The case of the García family, mentioned above, confirms these fusions: the mayor of Camiña is Sixto García, another example of the same legitimation mechanism. And so it goes on, as we find that the current community leaders of various towns were direct relatives of almost all the candidates for councilor and mayor of Colchane in the 2012 election.

These elites achieve a position within the community based on the recognition of an external third party (trade associations, labor unions, national political legitimacies) and they reinforce their interethnic position by appealing to the re-signification and even the re-establishment of ethnic structures at commune level. This need for recognition from the community of local elites usually privileges two mechanisms, both of which are applied in reinforcement of existing hierarchies: 
(a) Appropriation and reinvention of the community's ritual space. The need to re-appropriate traditional authority spaces is present in ceremonial or symbolically important practices, such as anatas and carnivals. In them, the big men invite the rest of the community to collective feasts that reaffirm, through enormous ostentatious expenditure, their prestige and superiority.

(b) Mediation between community and state and its offer. The need to control the distribution of benefits and other concessions offered by the state, through the appropriation of political mediation possible within the national space. The case of the García Mamani family, in Colchane, is a good example of the first mechanism. Despite the devaluation of traditional authorities, expressed in the very scarce competition to give continuity to the alférez figure of the Isluga carnival, David García Mamani accepted this position in 2012. The person who assumes this role becomes the host and must cover all the costs of this community festivity that takes place in February each year. In a lavish display of excess, this local potlatch reaffirms the symbolic power and authority of the hosting family, in a scene that overwhelms social competence. The generation of prestige based on collective debt thus generated tends to pervade all the activities of the community, burning the surplus obtained through successful external relations.

The alférez for 2012 explains the main characteristic of this ostentatious expenditure for the community, corroborating that a large family stands behind him. Thus the practice of ayni ${ }^{3}$ tends to be reduced to the strengthening of kinship bonds, losing its previous capacity to maintain tight union within the community, in which the social whole participated more of solidarity than of agonistic forms.

This is from me, but not just me, all of the support of my family; family is the most important, the family nucleus, either brothers or cousins and our customs, the famous ayni as we call it. It's like (...) today it benefits me, tomorrow it benefits you. In fact, my sister, for example, brought me a tarkead $a^{4} \ldots$ from Bolivia, that has a price. To get it here too, so she gives it to me with love. Tomorrow when she needs something, or her son, I will have to respond too... that's the way it's done.
The second mechanism, mediation and distribution of the official offer, is clearly expressed in the allocation of benefits to the community, either through the application of "particular" criteria in the distribution of subsidies, or the assignment of tenders -with the same criteria- to be carried out by public works contractors. Examples of this mechanism are: the construction of the new Colchane Square, a big infrastructure work on which the government spent hundreds of millions of chilean pesos; the delivery of "participative pavements"; and the construction of the new offices of the Colchane-Pisiga border control point. All of the projects are carried out by contractor or subcontractor firms linked to the big families. All of them are also somehow linked to the transport business, either directly through truck or bus fleets, or indirectly through ownership of the necessary machinery to build and maintain the roads 5 .

The mechanisms that we have highlighted in an analytical manner, as the manifestation of relationships of solidarity or reciprocity in the social body, are coupled consubstantially to agonistic movements that compose hierarchies and chains of debt, operating in parallel in the political, economic and ritual fields (Mauss 2008). In other words, the relationships of reciprocity and debt generated in the ritual occurrence of these communities can be resolved in the political field in which the state offer also participates ${ }^{6}$.

\section{The Construction of the Transport Business Fringe}

The processes of accumulation that have allowed a certain transport business boom in Colchane and Pisiga, and the development of a transport elite within aymara communities, are closely related to the development of a group of small transport entrepreneurs (the fringe or margin). They are in fact the majority, who are unable to get enough capital together to become part of the small group which owns bus and truck fleets for passenger and goods transport (the elite). We will describe how this fringe of the transport business is formed and then declines, opening towards other forms of economic activity. Some of these are traditional while others are related to the development of new global markets, such as is currently the case of quinoa production and commercialization.

The entry of aymaras or aymara families from Colchane into the goods and passenger transport 
business is marked by the decline of the agricultural and livestock economy, as has been discussed by various authors, and the consequent depopulation of towns in the interior (the high Andean plateau and the Andes mountains) (Gundermann and Vergara 2009; Van Kessel 2003). This process has currently resulted in the overwhelming presence of indigenous population in the urban areas on the coast or along the roads leading to it, for example Pozo Almonte, Alto Hospicio and Iquique in Chile. Beyond the perspectives that see in this process an essentialist loss of aymara substrate, the concrete fact is that the old communities, traditionally linked to economies and organization systems closely related with extensive use of interior territories, are currently in fact disseminated trans-locally, with economic activities that are often complementary, but for the most part with a large part of the population being economically active and well inserted in the labor markets of the big cities. As time goes by they visit their towns of origin less and less frequently, almost only for events that are exclusively ritual, linked to the continuity of certain traditional festivities such as anatas and carnivals.

In this sense, David García's memory fixes a time in which livestock represented the center of the local economy, while at the same time activating the communities' exploitation mechanisms:

Cattle herding was always, not the same, that has also been lost, for that reason the number of cattle has decreased, because I can remember, but it has always been common that people help each other or go to certain places, because my mother used to tell me that earlier, before for example this time, starting March, you had to migrate with the animals to the foothills, to the high plateau, to the foothills, but not through the gorges, but higher up...And then, there were, there were places to arrive at, houses, small houses, and then the people would get organized, I am going, yes I am going, because you had to go, there was grass for the cattle at that time, then the main thing was the organization, I had 100, the next guy and we would get 500 head together and go stay up there for three days, whatever the trip lasted, then it would come and of course that was all organized and everyone in the same direction.
This scenario, in which traditional economic activities have receded, leaves an empty space that is somehow occupied by the transport business. We do not mean to say that this has been the only economic sustenance of aymara families in recent decades - on the contrary, there has been a general insertion of young people into the educational systems and labor markets. But somehow, the transport business is an activity with quite an important anchorage in traditional territories, due to the fact that it makes use of the newly paved road between Iquique and Oruro in Bolivia. From here, the aymara follow one of two access paths or courses to this activity.

On the one hand there is access to this industry by aymaras and their families who have already migrated to the cities. Once inserted in the educational systems of the cities, and often without having had any previous contact with the transport industry, they carry out jobs linked to the economy of the Zofri, which makes extensive use of the road that crosses Colchane to send goods to Bolivia. Once in the city, the young people finish their compulsory basic education and later follow technical studies such as car mechanics, etc., which bring them into contact with the world of transport through a diversity of jobs, often as truck drivers.

This course, similar to the one followed in the case of the elite, can be represented by the family of Apolinario Castro in the town of Enquelga-some $20 \mathrm{~km}$ from Colchane and in the same communethat illustrates this dynamic well.

Apolinario's immediate family is composed of himself and his wife, and three sons who finished elementary school in Colchane. After finishing they moved to Iquique, specifically Alto Hospicio, where they finished high school and became associated with the Zofri in different jobs related to transport, from truck loaders to drivers. As Apolinario explains, through hard work in a number of different fields his sons have achieved economic independence and insertion in this economy through the purchase of a truck.

They went down there. Of course, it is good for them because you find a job quick, they go there, what do you call it?, to look for a job... With their trucks, a lot of people there have their trucks, they are loading and unloading they still keep on doing that. From here they are all staying 
here, the young ones, my sons, they all go loading and unloading.

-And have they bought trucks?

Yes, yes they have, and it has been good... Of course, in a day they got almost 60 or 80 lucas [thousand pesos] because, but you have to hit it hard, you're not gonna be sitting down there, in that time you have been unloading about five vehicles... so off you go to unload and (whistling) fast, sacks, for example, it goes fast, you put the other one, how to make it bigger, how to make it bigger.

Although in Colchane there is only one entrepreneur working with passenger buses, the registry of the Internal Revenue Service (SII) indicates that of the 26 enterprises registered in Colchane in 2010, twenty were in the commercial transport sector, automobiles or auto parts (Biblioteca del Congreso Nacional 2013).

As we have stated before, this migration to the cities is explained by or results from the depopulation of the towns of the interior and the decline of the agricultural economy. In the specific case of this family, the participation of the sons in the economy that their parents sustain in Colchane has been reduced to a minimum and they return almost exclusively for festivities or to invest in the prestige that becoming an alférez of some feast implies. Apolinario constantly talks about the difficulties of maintaining the animals and an agriculture that provides more than mere subsistence. All in all, the story of this family enables us to recognize forms of social mobility within these spaces, in terms of the formation of a market logic that enables movements and new forms of accumulation of power that can be expressed in both the economic and the political-ritual fields.

On the other hand, we have an example of insertion in this market through the acquisition of inherited knowledge from the family. Route 5 connecting Huara with Colchane, and thence Bolivia, was paved during the last decade, but has existed for much longer. Sergio Esteban's father was working in this activity in the decade of 1960s, and although he died young he managed to transfer a sort of "transport knowledge" to his son Sergio. The Esteban family is linked to the town of Chijo, near Cariquima, still in Colchane commune. Sergio's uncles, brothers and stepbrothers still live there, thus constituting the last stronghold of attachment to the soil of a family most of whose members now live in Alto Hospicio or Iquique.

Sergio is now over 60 years of age. He has devoted most of his life to the goods transport business; he has even owned a truck or two, but has not come close to becoming part of the transport elite we have described. Sergio himself recognizes that one of the reasons is the unequal competition established by the big transport enterprises based in Iquique, while another is the unfair competition from Bolivian businesses. In his own words, this part of the businesses takes place on the informal fringe, evading taxes that people like him have to pay. From our observations and conversations in the field we can infer that a part of the introduction of goods takes place illegally through unauthorized border crossings in the proximity of towns near to Colchane (where the bi-national border crossing is located) ${ }^{7}$. Entry of car transporters (known as cigüeñas [storks]) and other merchandise is controlled by merchants linked to the communities and the territories where these illegal crossings are located $^{8}$. It is in this context that car transport has become an important business in this region. Legal and illegal traffic, in the hands of the big families, ignites struggles for power over aymara territory. Transport by cigüeña makes a gross income of US $\$ 1,000$ per vehicle taken to Bolivia. The margin increases if the traffic takes place through an illegal border crossing, meaning a considerable profit considering that a cigüeña transports an average of 10 vehicles ${ }^{9}$. No clear distinction can be made of the legality or illegality of the products transported in this way; both possibilities must surely exist. What interests us here is the coordination of economies, networks and the uses made of the territory.

All in all, the many ways of carrying on this business, either formally or informally, have not been sufficient to enable merchants such as Sergio to step outside the "transport industry fringe" which we have described. The possibilities of greater economic accumulation are severely restricted by the strong local (also aymara), national and transnational competition affecting this route between Chile and Bolivia. In Sergio's specific case, after decades working in this activity, which is physically strenuous, he has sold his goods vehicle and taken a job as a small goods carrier for a wellknown construction materials and furniture store in Alto Hospicio. 
In this scenario, the transport business fringe sees in the latest global development of the quinoa market a way out of a complex situation in one of Chile's poorest communes, becoming a sort of utopia that begins with the viability and economic efficiency of quinoa harvesting in the Andean plateau and ends with the repopulation of the territories.

there we were, we had no other source of work, only to go to Cariquima and harvest quinoa, but our great ability is to get the best out of our land... Oh man, but if there were any possibilities, if a door would open and someone would tell me to put half for this machine and I finance you the other half I .....shhhiuuuu (whistling) I'd go to Chijo in a second, because I know that I am a farmer, I am a cattle herder, I am a bus driver and a truck driver, I've been there and done that, I went to Calama, Antofagasta, where have I not lived already, but I am not as happy anywhere else as I am on my land, I go to my town and I rest. In fact, today I still grow quinoa and I grow quinoa in Cariquima, we have land there.

Confidence that quinoa will trigger the economic rebirth of these high regions is part of a common understanding that is quite widespread among the various actors of these communities, based among other things on the support available in terms of resources and education delivered by the state through the municipality and the National Institute of Agricultural Development (INDAP $)^{10}$. In the framework of a transport economy that does not produce enough surplus for everybody, quinoa farming constitutes the newest imaginary for development in Colchane.

\section{Conclusion}

We have shown how a group of structural opportunities, linked to the development of crossborder transport and commerce, have allowed an elite group of businessmen to emerge in passenger and goods transport, and additionally a group of small entrepreneurs on the fringe; together they have displaced the centrality of agriculture and livestock farming in the economies of these territories (Van Kessel 1992), thus constituting the current symbolic and productive nucleus of the region. The new transport entrepreneurs have developed strategies that enable them to reconfigure their dominance over local power (both on the Chilean and the Bolivian sides of the frontier), using to their advantage the new relationships of "equal" recognition in the framework of national political power (Gundermann et al. 2003) and the "hierarchical" relationships that they have traditionally managed within the communities.

The members of this elite operate as "ethnic mediators" who enter this new market as differentiated actors competing for control of cross-border traffic with national and transnational enterprises. They control and channel the new relationships, and state benefits directed towards the local communities and ethnic groups, to their own advantage. We observe a trend for the current identity redefinition and the strengthening of market relations in these communities to end up reinforcing traditional lineages already operating in these spaces; they prove incapable of dissolving hierarchies that are allegedly weakened by exposure to market processes and free competition. The overlapping of political, economic and symbolic powers within these communities speaks of further consolidation of these hierarchies.

Nevertheless, the personal histories that describe the transport business fringe speak of how individuals and families act within the same market processes and opportunities that the free trade zone and the new road have created. Elite and Fringe participate jointly in town dominance in a force field that is no longer closed (recent hegemony of the trans-local), nor is it organized around a purely economic or instrumental dynamic. The practices observed are helping to define the interlocking of the political, economic and ritual spheres. It is certainly not a mere continuity of earlier organizational structures and forms of transport (e.g. those observed in the 19th century). Here we have important new differences, such as the influence of the context and influx of globalization, the central role assumed by the formation of national boundaries, the resulting new population flows between countries, and the technological factor. Together they lead to the construction of a new phenomenon and to social relations linked to these elements.

Acknowledgements: This work was supported by Fondecyt project 11110246 "Etnicidad y procesos translocales en espacios de frontera: migraciones internacionales en el norte de Chile". We also thank the evaluators of article. 


\section{References Cited}

Aduana Nacional de Chile. Estadísticas 2012. Available at: http://www.aduana. cl/prontus_aduana/site/artic/20070418/ pags/20070418155859. html (Accessed 3 April 2013).

Albó, X. 2002. Identidad Étnica y Política. Centro de Investigación y Promoción del Campesinado (CIPCA), La Paz.

Appadurai, A. 1991 [1986]. Introducción: Las Mercancías y la Política del Valor. En La Vida Social de la Cosas. Perspectiva Cultural de las Mercancías, edited by A. Appadurai, pp. 17-87. Grijalbo, México, D.F.

Biblioteca del Congreso Nacional (BCN) 2013. Reportes Estadísticos Comunales 2013. Available at: http://reportes comunales.bcn.cl/index.php/Colchane (Accessed 4 April 2013).

Bourdieu, P. 1997. Razones Prácticas: Sobre la Teoría de la Acción. Anagrama, Barcelona.

Burguete, A. 2011. Municipalización del gobierno indígena e indianización del gobierno municipal en América Latina. Revista Pueblos y Fronteras Digital 6:38-88.

De Munter, K. 2010. Tejiendo reciprocidades: John Murra y el contextualizar entre los aymara contemporáneos. Chungara Revista de Antropología Chilena 42:247-255.

Delgado, F. 2001. Simbiosis Interzonal en las Estrategias de Autodesarrollo Sostenible en Ecosistemas de Montaña: El Caso del Ayllu Mujlli, Departamento de Cochabamba, Bolivia. Doctoral Dissertation, Universidad de Córdoba, Córdoba.

Gundermann, H. 2013. Sociedades indígenas, municipio y etnicidad: la transformación de los espacios políticos locales andinos en Chile. Estudios Atacameños. Arqueología y Antropología Surandinas 25:55-77.

Gundermann, H., R. Foerster, and J. Vergara 2003. Mapuches y Aymaras: El Debate en torno al Reconocimiento y los Derechos Ciudadanos. Ediciones Universidad de Chile/PREDES/RIL, Santiago.

Gundermann, H. and J. Vergara 2009. Comunidad, organización y complejidad social andinas en el norte de Chile. Estudios Atacameños. Arqueología y Antropología Surandinas 38: 107-126.

Jiménez, Z. and J. Delgadillo 2010. Investigación Participativa en Gestión Territorial Indígena Originaria y Campesina: Ganadería Campesina y Gestión Territorial de la Comunidad Tallija-Confital, Ayllu Aransaya Provincia Tapacari (Cochabamba-Bolivia). AGRUCO/PIPRGT/PLURAL, Cochabamba.

Mauss, M. 2008 [1950]. Essai Sur le Don. Forme et Raison de L'échange dans les SocietésArchaiques. En Sociologie et Antropologie, edited by M. Mauss, pp.145-284. PUF, Paris.
Mendoza, M. 2007. Descentralización, Construcción Ciudadana y Capital Social en Bolivia: Un Análisis Social, Político y Económico con Estudios de Caso de la Zona Andina y Consideraciones Sobre Autonomías. Programa de Investigación Estratégica en Bolivia (PIEB), La Paz.

Murra, J. 1975. Formaciones Económicas y Políticas del Mundo Andino. Instituto de Estudios Peruanos, Lima.

Orellana, R. 2009. Municipalización de Pueblos Indígenas en Bolivia: Impactos y Perspectivas. En El Reto de la Diversidad. Pueblos Indígenas y Reforma del Estado en América Latina, edited by W. Assies, G. Van der Haar, and A. Hoekema, pp. 315340. El Colegio de Michoacán, México, D.F.

Perreault, T. 2006. From the Guerra del Agua to the Guerra del Gas: Resource governance, neoliberalism and popular protest in Bolivia. Antipode 38:150-172.

Sandoval, D., F. Chirino, and J. Gutiérrez 2013. Redes Económicas y Sociales: Reconfiguraciones en el Transporte Interprovincial en Santa Cruz. Programa de Investigación Estratégica en Bolivia (PIEB), La Paz.

Tassi, N. 2015. Pensando el mundo desde los márgenes: la expansión cosmológica y económica de los comerciantes aymaras en Bolivia. En Tecnologías en los Márgenes: Antropología, Mundos Materiales y Técnicas en América Latina, edited by P. Di Giminiani, S. González, M. Murray, and H. Risor, pp. 43-66. Bonilla Artigas Editores, Mexico, D.F.

Tassi, N., A. Hinojosa, and R. Canaviri 2014. La economía popular en Bolivia: tres miradas. Vicepresidencia del Estado, Presidencia de la Asamblea Legislativa Plurinacional, La Paz.

Van Kessel, J. 1992 [1981]. Holocausto al Progreso: Los Aymara de Tarapacá. Hisbol, La Paz.

Van Kessel, J. 2003. La empresa salitrera: el primer milagro económico chileno y el último capítulo de la historia de la comunidad aymara en Tarapacá. Cuadernos de Investigación en Cultura y Tecnología Andina IECTA-Chile 15:1-27. Available at: http://www.iecta.cl/biblioteca/cuadernos/html/cuaderno_15. html(Accessed 1 March 2014).

Yánez, N. and R. Molina 2008. La Gran Minería y los Derechos Indígenas en el Norte de Chile. LOM Ediciones, Santiago.

Zamorano, Y. 2012. Análisis estadístico del Programa de Saneamiento Legal de Vehículos 2011: base de datos de los vehículos saneados según la Ley $\mathrm{N}^{\circ} 133$ : Documento de trabajo de la Aduana Nacional de Bolivia. Available at: http://www. aduana.gob.bo/An\%C3\%A1lisis\%20Programa\%20de\%20 Saneamiento\%202011.pdf (Accessed 7 May 2013).

Zenteno, H. 2009. Acercamiento a la visión cósmica del mundo andino. Punto Cero 14/18:83-89.

\section{Notes}

1 The problem of tension between individualist and communitarian forces in aymara culture have been recorded diachronically by Albó (2002).

2 Civil appointment with strong religious connotations, which are what currently differentiate it from the new union leaders. Originally the role of the jilakata was to observe the development of community crops and to protect them from damage caused by livestock. The post is passed on by turns with a yearly duration; a person is appointed once in a lifetime and it constitutes an unavoidable responsibility 
(Delgado 2001:170-172; Jiménez and Delgadillo 2010; Zenteno 2009).

3 Collective work system based on reciprocity between families, especially used in agricultural and construction activities and in other actions linked to schools and neighborhoods (De Munter 2010; Mendoza 2007). For Murra, in the Andean economy this means reciprocity among relatives and neighbors, including agricultural, cattle herding and construction activities (Murra 1975).

4 Traditional dance to the music of tarkas (small Andean flutes).

5 A phenomenon with similar characteristics, of condensation of political power in pressure groups linked to the transport industry, can be seen in some of the town halls of the Santa Cruz department, Bolivia, in a parallel phenomenon that should be further investigated (Sandoval et al. 2013).

6 According to De Munter, in the Andean world cultural -political, ritual and economic-practices intertwine different reciprocities that expose both positive and negative facets, such as the duty of vengeance and duties generated by gifts (De Munter 2010). On the same topic, Appadurai develops a comparative focus to understand these types of interrelations between economy and society, simultaneously articulating traditional systems of reciprocity with modern or capitalist forms of relationship. Appadurai states: "Of course there exist many differences of scale, media, context and goals between the kula and the merchandise markets of future delivery. Nevertheless, the similarities are real and, as I have already pointed out, many societies create specialized fields for value struggles, where specialized mercantile symbols are negotiated with and such a commerce has an influence, through economies of status, power or wealth in the most mundane of mercantile flows" (Appadurai 1991 [1986]:50).

7 The main goods that are introduced into Bolivia, both legally and illegally, are motorized vehicles, machinery, major appliances, electronics, used clothing, etc.

8 Within the Colchane commune we distinguish two illegal passes that are commonly used to smuggle merchandise to Bolivia. On the north side of Colchane there is a pass through Pampa Parajalla (better known as Puerto Rico), and through the south, in the Cariquima sector, there are passes through the towns of Ancovinto and Panavinto, next to the Coipasa salt flat.

9 It should be recorded that in 2011 Evo Morales' government passed Law Nr. 133, Legal Regularization of Vehicles, to regularize the status of those that had been introduced illegally into the country. In the four months of its application 67,077 vehicles were registered, all of which entered the program and were legalized in the National Bolivian Customs (Zamorano 2012).

10 Merchants and landowners identify two areas as important for the development of quinoa crops in Colchane. Access to soft loans that enable them to invest in machinery in order to practice more intensive agriculture, and diversification of the agents that buy their production, in order to free themselves from almost exclusive dependence on the Bolivian buyers who currently have the upper hand in this business. 
